\title{
Nocardia harenae sp. nov., an actinomycete isolated from beach sand
}

\author{
Jae Pyo Seo and Soon Dong Lee \\ Department of Science Education, Cheju National University, Jeju 690-756, Republic of Korea
}

Correspondence

Soon Dong Lee

sdlee@cheju.ac.kr

\begin{abstract}
A novel actinomycete, strain WS-26 ${ }^{\top}$, was isolated from beach sand on the coast of Jeju Island, Republic of Korea, and subjected to a polyphasic taxonomic characterization. The organism produced reddish orange-coloured substrate mycelium and white aerial mycelium, both of which fragmented into rod-shaped elements. A neighbour-joining tree, based on 16S rRNA gene sequence studies, revealed that the isolate formed a distinct branch at the base of a cluster that included Nocardia carnea, N. flavorosea, N. pigrifrangens, N. sienata and N. testacea. This branching pattern was also found in a tree constructed using the maximum-likelihood method, but was not supported by the maximum-parsimony method. Levels of 16S rRNA gene sequence similarity between the isolate and its phylogenetic neighbours ranged from $96 \cdot 5$ to $97 \cdot 8 \%$. Chemotaxonomic properties, such as the principal amino acid of peptidoglycan, predominant menaquinone and polar lipids, supported its assignment to the genus Nocardia. On the basis of phenotypic and phylogenetic data, the organism was different from Nocardia species with validly published names. The name Nocardia harenae sp. nov. is proposed, with WS-26 ${ }^{\top}(=\mathrm{KCCM}$ $42317^{\top}=\mathrm{NRRL} B-24459^{\top}$ ) as the type strain.
\end{abstract}

During the study of marine actinomycetes on the coast of Jeju Island, Republic of Korea, strain WS- $26^{\mathrm{T}}$ was isolated from a sand plain on a beach. A dried sand sample was taken and placed directly into a sterilized $50 \mathrm{ml}$ Falcon tube. For bacterial isolation, a sand sample $(1 \mathrm{~g})$ was placed into a sterile plastic tube containing $9 \mathrm{ml}$ sterile distilled water and mixed in a tube rotator for $30 \mathrm{~min}$ at moderate speed. Aliquots $(100 \mu \mathrm{l})$ of serial dilutions of the samples were transferred to plates of SC-SW agar [1\% soluble starch, $0.03 \%$ casein, $0.2 \% \quad \mathrm{KNO}_{3}, \quad 0.2 \% \mathrm{NaCl}, \quad 0.002 \%$ $\mathrm{CaCO}_{3}, 1.8 \%$ agar, $0.005 \% \mathrm{MgSO}_{4} \cdot 7 \mathrm{H}_{2} \mathrm{O}$ and $0.001 \%$ $\mathrm{FeSO}_{4} .7 \mathrm{H}_{2} \mathrm{O}$ in a mixture of $60 \%$ natural seawater and $40 \%$ distilled water ( $\mathrm{pH} 7 \cdot 2)]$. After incubation at $30^{\circ} \mathrm{C}$ for 14 days, colonies were subcultured on YE-SW medium $(0.4 \%$ yeast extract, $1.0 \%$ malt extract, $0.4 \%$ glucose and $1.8 \%$ agar in a mixture of $60 \%$ natural seawater and $40 \%$ distilled water) and pure cultures were maintained as mycelial fragments in a $20 \%$ glycerol suspension at $-84^{\circ} \mathrm{C}$.

Strain WS $-26^{\mathrm{T}}$ was subjected to morphological, cultural, physiological and chemotaxonomic characterization, in addition to phylogenetic analysis based on 16S rRNA gene sequence studies. Based on the phenotypic and phylogenetic data, it was shown that the organism was different from species of the genus Nocardia with validly published names.

The GenBank/EMBL/DDBJ accession number for the $16 \mathrm{~S}$ rRNA gene sequence of strain WS-26 ${ }^{\top}$ is DQ282122.
Morphological characteristics were investigated by light microscopy. Cells were incubated on oatmeal agar for 14 days at $30{ }^{\circ} \mathrm{C}$. A coverslip with growing cells attached was observed directly using a light microscope. The degree of growth and the level of pigmentation were investigated on ISP 2, ISP 3 and ISP 4 agar media (Shirling \& Gottlieb, 1966) and tryptic soy broth (Difco) supplemented with agar (TSBA) after incubation at $30^{\circ} \mathrm{C}$ for 14 days. Strain WS- $26^{\mathrm{T}}$ showed good growth on ISP 2 medium and TSBA, but only moderate growth on ISP 3 and ISP 4 media. Abundant, branched substrate mycelium, which was reddish orange in colour, was produced on all of the media tested and fragmented into irregular rod-shaped elements. The intensity of pigmentation was stronger on the nutrientrich media, namely ISP 2 medium and TSBA. Diffusible pigments were not produced on most of the media tested. White, fragmenting aerial mycelium was produced to a moderate level on ISP 3 and ISP 4 media, but was sparse on ISP 2 medium and TSBA.

Genomic DNA was extracted and purified as described previously (Lee, 2006). The $16 \mathrm{~S}$ rRNA gene of strain WS- $26^{\mathrm{T}}$ was amplified by PCR as described previously (Lee et al., 2000a) and purified using the Wizard PCR Preps DNA purification system (Promega). The resultant 16S rRNA gene was sequenced directly using an ABI PRISM BigDye Terminator Cycle Sequencing kit (Applied Biosystems) and an automatic DNA sequencer (model 3730xl; Applied Biosystems). An almost complete $16 \mathrm{~S}$ rRNA gene sequence 
of strain WS- $26^{\mathrm{T}}$ was determined in this study and comprised a continuous stretch of $1397 \mathrm{nt}$. The sequence was subjected to a BLAST search (http://www.ncbi.nlm.nih.gov/), which indicated that the organism was a member of the family Nocardiaceae. Assignment to this family was also supported by the presence of a set of family-specific signature nucleotides in the $16 \mathrm{~S}$ rRNA gene sequence (Stackebrandt et al., 1997).

CLUSTAL_X (Thompson et al., 1997) was used to align the sequence with available reference sequences retrieved from GenBank. Multiple alignments were optimized manually according to $16 \mathrm{~S}$ rRNA secondary structure. Phylogenetic analyses were carried out using three treeing algorithms, the neighbour-joining (Saitou \& Nei, 1987), maximum-likelihood (Felsenstein, 1981) and maximum-parsimony (Fitch, 1971) methods. A total of 1257 unambiguous aligned positions present in all strains between nt 91 and 1392 (nucleotide numbering according to Escherichia coli positions; Brosius et al., 1978) was used for phylogenetic analyses. A phylogenetic tree was reconstructed by the neighbourjoining method from evolutionary distances calculated by the method of Jukes \& Cantor (1969). Tsukamurella paurometabola DSM $20162^{\mathrm{T}}$ (GenBank accession no. X80628) was used as an outgroup. The reliability of the tree topology was evaluated by bootstrap analysis (Felsenstein, 1985).

The 16S rRNA gene sequence was compared with those of the 59 type strains of Nocardia species with validly published names at the time of writing. A neighbour-joining tree (Fig. 1), based on 16S rRNA gene sequence studies, showed that the organism formed the deepest branch outside the Nocardia carnea cluster, which included Nocardia carnea, $N$. flavorosea, $N$. pigrifrangens, $N$. sienata and $N$. testacea, with a bootstrap value of $41 \%$. This phylogenetic placement was also found in the tree constructed using the maximumlikelihood method, although strain WS- $26^{\mathrm{T}}$ formed a cluster with Nocardia transvalensis when the maximum-parsimony method was employed (not shown). Levels of 16S rRNA gene sequence similarity between strain WS- $26^{\mathrm{T}}$ and members of the genus Nocardia ranged from 94.6 to $97 \cdot 9 \%$. The organism showed high $16 \mathrm{~S}$ rRNA gene sequence similarity values to closely associated neighbours, namely $N$. carnea DSM $43398^{\mathrm{T}}(97 \cdot 8 \%)$, Nocardia cyriacigeorgica DSM $44484^{\mathrm{T}}(97 \cdot 8 \%), N$. flavorosea JCM $3332^{\mathrm{T}}(97 \cdot 7 \%), N$. pigrifrangens JCM $11884^{\mathrm{T}}(96 \cdot 5 \%)$, N. sienata IFM $10088^{\mathrm{T}}$ $(97 \cdot 7 \%)$ and N. testacea IFM $0937^{\mathrm{T}}(97 \cdot 8 \%)$. Among loosely associated members, Nocardia abscessus DSM $44432^{\mathrm{T}}$, Nocardia asiatica IFM $0245^{\mathrm{T}}$, Nocardia brasiliensis ATCC $19296^{\mathrm{T}}$ and N. transvalensis DSM $43405^{\mathrm{T}}$ (sequence similarity values of $97 \cdot 7-97 \cdot 9 \%$ ) were equidistantly related to strain WS- $26^{\mathrm{T}}$, representing slightly higher values than those between the isolate and its phylogenetic neighbours. The unstable topology of the isolate in the tree (Fig. 1), as well as the somewhat low sequence similarities to the type strains of the genus Nocardia, indicated that strain WS $-26^{\mathrm{T}}$ merits classification as a novel genomic species without the need to perform DNA-DNA hybridization experiments.
The following chemotaxonomic analyses were performed as indicated: analysis of mycolic acids (Minnikin et al., 1980), phospholipids (Minnikin et al., 1977), lipoquinones (Kroppenstedt, 1985), the isomer of diaminopimelic acid (Staneck \& Roberts, 1974) and the acyl type (Uchida \& Aida, 1984) of the peptidoglycan and the whole-cell sugar composition (Saddler et al., 1991). Cellular fatty acids were extracted from biomass obtained in trypticase soy broth (Difco) incubated at $30^{\circ} \mathrm{C}$ for 3 days. Fatty acid methyl esters were prepared by alkaline methanolysis (Minnikin, 1988) and analysed using a gas chromatograph (model 6850; Agilent) as described previously (Lee et al., 2000b). The $\mathrm{G}+\mathrm{C}$ content of the DNA was determined by HPLC as described previously (Mesbah et al., 1989). The results of chemical analyses, particularly the predominant lipoquinone, revealed that the organism could be assigned to the genus Nocardia (Collins et al., 1977). Whole-cell hydrolysates contained arabinose and galactose as characteristic sugars and meso-diaminopimelic acid as the principal diamino acid (type IV cell wall; Lechevalier \& Lechevalier, 1970). The glycan moiety of the murein was $N$-acetylated. The predominant lipoquinone was a tetrahydrogenated menaquinone with eight isoprene units in which the two terminal isoprene moieties were cyclized [MK- $8\left(\mathrm{H}_{4}, \omega\right.$-cycl $\left.)\right]$. This type of lipoquinone is found in all species of the genus Nocardia (Collins et al., 1977). Mycolic acids were present, with an $R_{\mathrm{f}}$ value of 0.47 on TLC. The phospholipids detected were phosphatidylethanolamine, phosphatidylinositol and diphosphatidylglycerol (phospholipid type PII pattern; Lechevalier et al., 1977). Cellular fatty acid profiles were characterized by the predominance of hexadecanoic $\left(\mathrm{C}_{16: 0}\right.$; $25 \cdot 3 \%)$, tuberculostearic (10-methyl- $\left.\mathrm{C}_{18: 0} ; 16.7 \%\right)$ and cis-9-octadecenoic (cis9- $\left.\mathrm{C}_{18: 1} ; 12 \cdot 7 \%\right)$ acids, followed by 16-methylheptadecanoic (i-C $18: 0 ; 8 \cdot 4 \%)$, octadecanoic $\left(\mathrm{C}_{18: 0} ; 6 \cdot 3 \%\right)$ and 2-hydroxytetradecanoic (2-OH- $\mathrm{C}_{14: 0}$; $5 \cdot 2 \%)$ acids. Minor amounts of other saturated, iso- and anteiso-branched fatty acids were also detected in the wholecell methanolysates.

The following physiological tests were performed using previously described methods (Lee, 2006): production of hydrogen sulfide, nitrate reduction, gelatin liquefaction, hydrolysis of casein, aesculin and starch and degradation of adenine, hypoxanthine, DL-tyrosine and xanthine. For hydrolysis and decomposition tests, strain WS- $26^{\mathrm{T}}$ was grown on YE-SW agar as the basal medium. Gram staining and oxidase tests were carried out using the method of MacFaddin (1980). Catalase activity was determined with a $3 \%(\mathrm{v} / \mathrm{v})$ hydrogen peroxide solution. Urease activity was determined by a colour change in Bacto urea broth (Difco). $\mathrm{NaCl}$ tolerance was tested by growth on yeast extract/malt extract agar (ISP 2 medium) supplemented with $\mathrm{NaCl}$ at final concentrations of $0-9 \%(\mathrm{w} / \mathrm{v})$. Growth was tested at temperatures of $4,10,20,30,37$ and $45^{\circ} \mathrm{C}$ and at $\mathrm{pH} 4 \cdot 1-$ $10 \cdot 1$ (at intervals of $1 \cdot 0$ ) using YE-SW agar as the basal medium. Utilization of carbohydrates, alcohols and organic acids as sole carbon and energy sources was tested using ISP 9 medium (Shirling \& Gottlieb, 1966) containing 


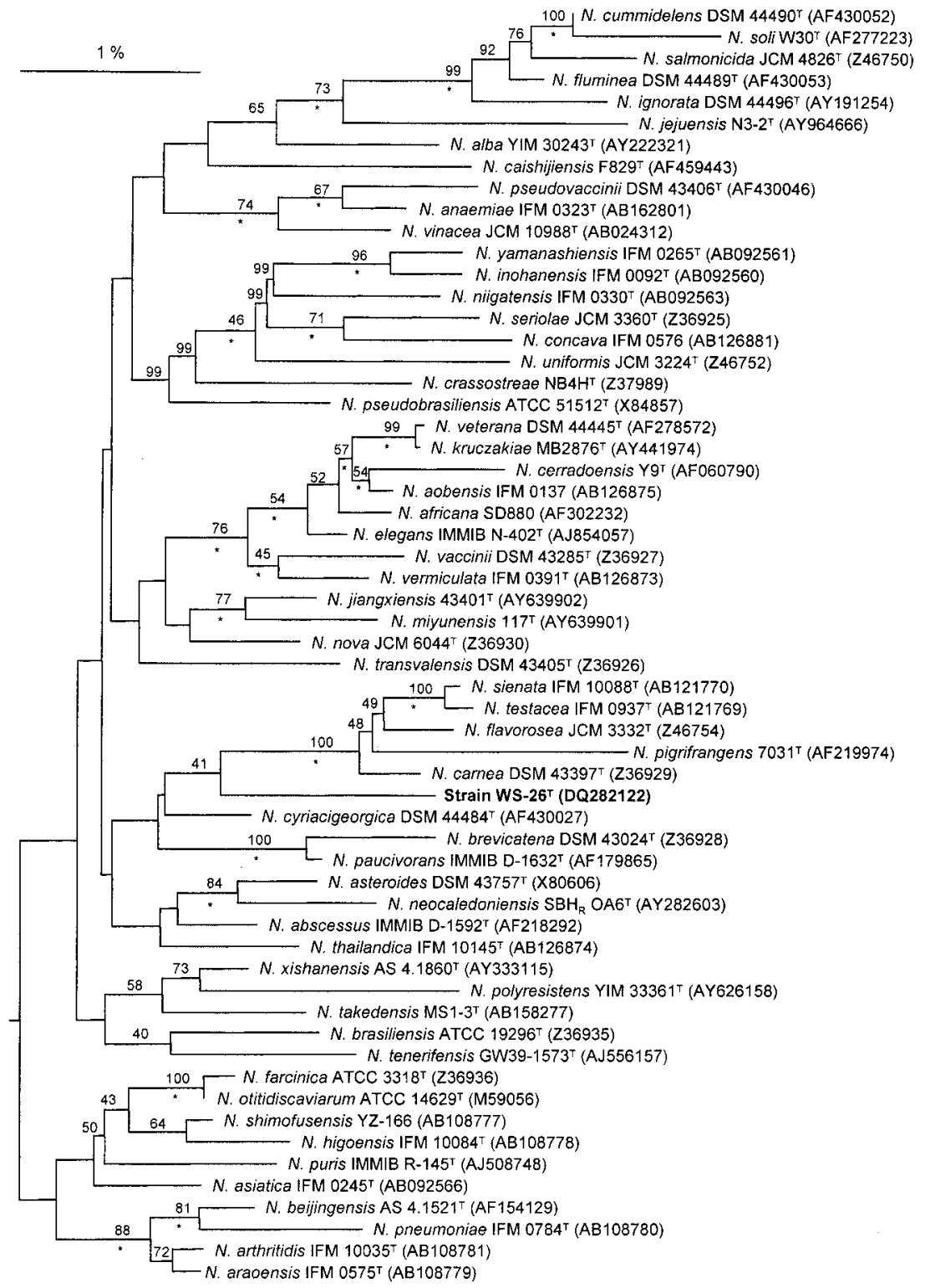

Fig. 1. Neighbour-joining tree based on 16S rRNA gene sequences showing the phylogenetic position of strain WS- $26^{\top}$ within the Nocardia radiation. Numbers at nodes indicate percentages of bootstrap support based on a neighbour-joining analysis of 1000 replications (only values greater than $40 \%$ are indicated). Asterisks indicate branches of the tree that were recovered using both maximum-likelihood (Felsenstein, 1981) and maximum-parsimony (Fitch, 1971) tree-making algorithms. Bar, 1 substitution per 100 nucleotide positions. filter-sterilized carbon sources at final concentrations of $1 \%$ (w/v) for carbohydrates and alcohols and $0 \cdot 1 \%(\mathrm{w} / \mathrm{v})$ for organic acids. The results of morphological, cultural and physiological tests are given in the species description and in Table 1. Strain WS $-26^{\mathrm{T}}$ utilized a limited range of carbohydrates and organic acids as the sole carbon source. Interestingly, strain WS $-26^{\mathrm{T}}$ showed growth over a broad $\mathrm{pH}$ range of $4 \cdot 1-10 \cdot 1$. The ability to grow at $\mathrm{pH} 4 \cdot 1$ may be a key characteristic for identification of strain WS-26 ${ }^{\mathrm{T}}$, as most nocardial strains do not grow under acidic conditions.

The type strains of $N$. abscessus, $N$. asiatica, N. brasiliensis and $N$. transvalensis, which showed high sequence similarity values of $97 \cdot 8-97 \cdot 9 \%$, albeit with loosely associated relationships in the neighbour-joining tree (Fig. 1), could be differentiated from the isolate on the basis of cultural and physiological features, as well as the origin of isolation (Lechevalier, 1989; Chun et al., 1998; Yassin et al., 2000, 2003; Kageyama et al., 2004a, b; Wang et al., 2004). The phenotypic properties that differentiated the isolate from its phylogenetic relatives are given in Table 1 . In particular, strain WS- $26^{\mathrm{T}}$ was readily distinguished from N. transvalensis, which formed a phylogenetic cluster with the isolate in the tree constructed using the maximum-parsimony method (data not shown), by pigmentation of the substrate mycelium (Lechevalier, 1989), in the utilization of D-xylose, meso-erythritol, D-sorbitol and acetate, in the decomposition of hypoxanthine and in nitrate reduction (Table 1). The results of polyphasic taxonomic characterization strongly suggest that the organism be classified as a novel species of the genus Nocardia. The name Nocardia harenae sp. nov. is proposed, with WS- $26^{\mathrm{T}}$ as the type strain. 
Table 1. Phenotypic characteristics that distinguish strain WS-26 ${ }^{\top}$ from its phylogenetic relatives in the genus Nocardia

Strains/species: 1 , WS-26 ${ }^{\mathrm{T}} ; 2$, N. asiatica; 3, N. brasiliensis; 4, N. carnea; 5, N. cyriacigeorgica; 6, N. flavorosea; 7, N. pigrifrangens; 8, N. sienata; 9, N. testacea; 10, N. transvalensis. Data were taken from Lechevalier (1989), Chun et al. (1998), Kageyama et al. (2004a, b), Wang et al. (2004), Yassin et al. (2001, 2003) and this study. +, Positive; -, negative; V, strain-dependent; ND, no data available.

\begin{tabular}{|c|c|c|c|c|c|c|c|c|c|c|}
\hline Characteristic & 1 & 2 & 3 & 4 & 5 & 6 & 7 & 8 & 9 & 10 \\
\hline $\begin{array}{l}\text { Colour of substrate } \\
\text { mycelium }\end{array}$ & $\begin{array}{l}\text { Reddish } \\
\text { orange }\end{array}$ & Yellow & $\begin{array}{l}\text { Orange } \\
\text { to } \tan \end{array}$ & $\begin{array}{l}\text { Cream } \\
\text { to peach }\end{array}$ & ND & Orange & Orange & Pale yellow & $\begin{array}{l}\text { Orange } \\
\text { to brick }\end{array}$ & $\begin{array}{l}\text { Pale tan } \\
\text { to cream }\end{array}$ \\
\hline \multicolumn{11}{|l|}{ Utilization of: } \\
\hline Acetate & - & + & + & - & + & + & + & $\mathrm{ND}$ & ND & + \\
\hline Adonitol & - & - & - & - & - & - & - & - & - & + \\
\hline meso-Erythritol & - & - & - & ND & - & ND & + & - & - & + \\
\hline D-Glucose & + & + & + & + & - & - & + & + & + & + \\
\hline L-Rhamnose & - & + & - & - & - & - & - & - & + & + \\
\hline D-Sorbitol & - & - & - & + & - & - & - & - & - & + \\
\hline D-Xylose & + & $\mathrm{ND}$ & - & - & - & - & + & $\mathrm{ND}$ & $\mathrm{ND}$ & - \\
\hline \multicolumn{11}{|l|}{ Decomposition of: } \\
\hline Casein & - & - & + & - & - & - & - & - & - & - \\
\hline Hypoxanthine & - & - & + & - & - & - & - & - & - & + \\
\hline Urea & + & $\mathrm{V}$ & - & - & + & - & + & - & - & + \\
\hline Nitrate reduction & - & + & + & + & + & - & ND & ND & $\mathrm{ND}$ & + \\
\hline Growth at $45^{\circ} \mathrm{C}$ & - & - & + & - & - & + & - & - & + & - \\
\hline Origins of strains & $\begin{array}{l}\text { Beach } \\
\text { sand }\end{array}$ & $\begin{array}{l}\text { Clinical } \\
\text { samples }\end{array}$ & $\begin{array}{l}\text { Clinical } \\
\text { samples }\end{array}$ & $\begin{array}{l}\text { Soil and } \\
\text { air }\end{array}$ & $\begin{array}{l}\text { Clinical } \\
\text { samples }\end{array}$ & Soil & $\begin{array}{c}\text { Contaminated } \\
\text { agar plate }\end{array}$ & $\begin{array}{l}\text { Clinical } \\
\text { samples }\end{array}$ & $\begin{array}{l}\text { Clinical } \\
\text { samples }\end{array}$ & $\begin{array}{l}\text { Clinical } \\
\text { samples }\end{array}$ \\
\hline
\end{tabular}

\section{Description of Nocardia harenae sp. nov.}

Nocardia harenae (ha.re'nae. L. gen. n. harenae of sand, referring to the isolation of the type strain from beach sand).

Forms a well-developed and branched substrate mycelium that fragments into irregular rod-shaped elements. The colour of the substrate mycelium is reddish orange. White aerial mycelium is produced to a moderate level on ISP 3 and ISP 4 media, but is sparse on ISP 2 and TSBA. Aerobic, Gram-positive, acid-alcohol-fast, catalase-positive, ureasepositive and non-motile. $\mathrm{H}_{2} \mathrm{~S}$ is not produced. Nitrate is not reduced to nitrite. Gelatin liquefaction does not occur. Aesculin is hydrolysed, but not starch or casein. Growth occurs between 10 and $40{ }^{\circ} \mathrm{C}$. The $\mathrm{pH}$ range for growth is $4 \cdot 1-10 \cdot 1$. Growth occurs in the presence of $0-5 \% \mathrm{NaCl}$, but not $6-9 \% \mathrm{NaCl}$. Hypoxanthine, DL-tyrosine, elastin and xanthine are not degraded. Dextrin, D-glucose, sucrose, Dtrehalose, malate, succinate and D-xylose are used as sole carbon and energy sources, but not adonitol, D-arabinose, Larabinose, 2,3-butanediol, meso-erythritol, myo-inositol, inulin, D-lactose, D-mannose, D-melezitose, melibiose, methyl $\alpha$-D-glucoside, methyl $\alpha$-D-mannoside, 1,2-propanediol, D-raffinose, L-rhamnose, L-ribose, salicin, D-sorbitol, L-sorbose or D-xylitol. Utilization of D-cellobiose, D-dulcitol, D-fructose, glycerol, maltose and D-mannitol shows a weak response. Assimilation of malate and succinate is observed, but not of acetate, benzoate, citrate, formate or D-tartrate. The predominant cellular fatty acids are $\mathrm{C}_{16: 0}$, 10-methyl- $\mathrm{C}_{18: 0}$, cis9- $\mathrm{C}_{18: 1}, \mathrm{i}-\mathrm{C}_{18: 0}, \mathrm{C}_{18: 0}$ and 2-OH- $\mathrm{C}_{14: 0}$ acids. The $\mathrm{G}+\mathrm{C}$ content of the DNA is $68.9 \mathrm{~mol} \%$.
The type strain is strain WS $-26^{\mathrm{T}}\left(=\mathrm{KCCM} 42317^{\mathrm{T}}=\mathrm{NRRL}\right.$ $\mathrm{B}-24459^{\mathrm{T}}$ ), isolated from beach sand on the coast of Jeju Island, Republic of Korea.

\section{Acknowledgements}

This work was supported by the 21C Frontier Microbial Genomics and Application Center Program, Ministry of Science \& Technology, Republic of Korea.

\section{References}

Brosius, J., Palmer, J. L., Kennedy, J. P. \& Noller, H. F. (1978). Complete nucleotide sequence of a $16 \mathrm{~S}$ ribosomal RNA gene from Escherichia coli. Proc Natl Acad Sci U S A 75, 4801-4805.

Chun, J., Seong, C.-N., Bae, K. S., Lee, K.-J., Kang, S.-O., Goodfellow, M. \& Hah, Y. C. (1998). Nocardia flavorosea sp. nov. Int J Syst Bacteriol 48, 901-905.

Collins, M. D., Pirouz, T., Goodfellow, M. \& Minnikin, D. E. (1977). Distribution of menaquinones in actinomycetes and corynebacteria. J Gen Microbiol 100, 221-230.

Felsenstein, J. (1981). Evolutionary trees from DNA sequences: a maximum likelihood approach. J Mol Evol 17, 368-376.

Felsenstein, J. (1985). Confidence limits on phylogenies: an approach using the bootstrap. Evolution 39, 783-791.

Fitch, W. M. (1971). Towards defining the course of evolution: minimum change for a specific tree topology. Syst Zool 20, 406-416.

Jukes, T. H. \& Cantor, C. R. (1969). Evolution of protein molecules. In Mammalian Protein Metabolism, pp. 21-132. Edited by H. N. Munro. New York: Academic Press. 
Kageyama, A., Poonwan, N., Yazawa, K., Mikami, Y. \& Nishimura, K. (2004a). Nocardia asiatica sp. nov., isolated from patients with nocardiosis in Japan and clinical specimens from Thailand. Int J Syst Evol Microbiol 54, 125-130.

Kageyama, A., Yazawa, K., Nishimura, K. \& Mikami, Y. (2004b). Nocardia testaceus sp. nov. and Nocardia senatus sp. nov., isolated from patients in Japan. Microbiol Immunol 48, 271-276.

Kroppenstedt, R. M. (1985). Fatty acid and menaquinone analysis of actinomycetes and related organisms. In Chemical Methods in Bacterial Systematics, pp. 173-199. Edited by M. Goodfellow \& D. E. Minnikin. London: Academic Press.

Lechevalier, H. A. (1989). Nocardioform actinomycetes. In Bergey's Manual of Systematic Bacteriology, vol. 4, pp. 2348-2404. Edited by S. T. Williams, M. E. Sharpe \& J. G. Holt. Baltimore: Williams \& Wilkins.

Lechevalier, M. P. \& Lechevalier, H. (1970). Chemical composition as a criterion in the classification of aerobic actinomycetes. Int J Syst Bacteriol 20, 435-443.

Lechevalier, M. P., De Bièvre, C. \& Lechevalier, H. A. (1977) Chemotaxonomy of aerobic actinomycetes: phospholipid composition. Biochem Ecol Syst 5, 249-260.

Lee, S. D. (2006). Nocardia jejuensis sp. nov., a novel actinomycete isolated from a natural cave on Jeju Island, Republic of Korea. Int J Syst Evol Microbiol 56, 559-562.

Lee, S. D., Kang, S.-O. \& Hah, Y. C. (2000a). Hongia gen. nov., a new genus of the order Actinomycetales. Int J Syst Evol Microbiol 50, 191-199.

Lee, S. D., Kim, E. S., Roe, J.-H., Kim, J.-H., Kang, S.-O. \& Hah, Y. C. (2000b). Saccharothrix violacea sp. nov., isolated from a gold mine cave, and Saccharothrix albidocapillata comb. nov. Int J Syst Evol Microbiol 50, 1315-1323.

MacFaddin, J. F. (1980). Biochemical Tests for Identification of Medical Bacteria, 2nd edn. Baltimore: Williams \& Wilkins.

Mesbah, M., Premachandran, U. \& Whitman, W. B. (1989). Precise measurement of the $\mathrm{G}+\mathrm{C}$ content of deoxyribonucleic acid by highperformance liquid chromatography. Int J Syst Bacteriol 39, 159-167.

Minnikin, D. E. (1988). Isolation and purification of mycobacterial wall lipids. In Bacterial Cell Surface Techniques, pp. 125-135. Edited by I. C. Hancock \& I. R. Poxton. Chichester: Wiley.
Minnikin, D. E., Alshamaony, L. \& Goodfellow, M. (1977). Differentiation of Mycobacterium, Nocardia, and related taxa by thin layer chromatographic analysis of whole-cell methanolysates. $J$ Gen Microbiol 88, 200-204.

Minnikin, D. E., Hutchinson, I. G., Caldicott, A. B. \& Goodfellow, M. (1980). Thin layer chromatography of methanolysates of mycolic acid-containing bacteria. J Chromatogr 188, 221-233.

Saddler, G. S., Tavecchia, P., Lociuro, S., Zanol, M., Colombo, E. \& Selva, E. (1991). Analysis of madurose and other actinomycete whole cell sugars by gas chromatography. J Microbiol Methods 14, 185-191.

Saitou, N. \& Nei, M. (1987). The neighbor-joining method: a new method for reconstructing phylogenetic trees. Mol Biol Evol 4, 406-425.

Shirling, E. B. \& Gottlieb, D. (1966). Methods for characterization of Streptomyces species. Int J Syst Bacteriol 16, 313-340.

Stackebrandt, E., Rainey, F. A. \& Ward-Rainey, N. L. (1997). Proposal for a new hierarchic classification system, Actinobacteria classis nov. Int J Syst Bacteriol 47, 479-491.

Staneck, J. L. \& Roberts, G. D. (1974). Simplified approach to identification of aerobic actinomycetes by thin-layer chromatography. Appl Microbiol 28, 226-231.

Thompson, J. D., Gibson, T. J., Plewniak, F., Jeanmougin, F. \& Higgins, D. G. (1997). The CLUSTAL_X windows interface: flexible strategies for multiple sequence alignment aided by quality analysis tools. Nucleic Acids Res 25, 4876-4882.

Uchida, K. \& Aida, K. (1984). An improved method for the glycolate test for simple identification of the acyl type of bacterial cell walls. J Gen Appl Microbiol 30, 131-134.

Wang, L., Zhang, Y., Huang, Y., Maldonado, L. A., Liu, Z. \& Goodfellow, M. (2004). Nocardia pigrifrangens sp. nov., a novel actinomycete isolated from a contaminated agar plate. Int J Syst Evol Microbiol 54, 1683-1686.

Yassin, A. F., Rainey, F. A., Mendrock, U., Brzezinka, H. \& Schaal, K. P. (2000). Nocardia abscessus sp. nov. Int J Syst Evol Microbiol 50, 1487-1493.

Yassin, A. F., Rainey, F. A. \& Steiner, U. (2001). Nocardia cyriacigeorgici sp. nov. Int J Syst Evol Microbiol 51, 1419-1423.

Yassin, A. F., Sträubler, B., Schumann, P. \& Schaal, K. P. (2003). Nocardia puris sp. nov. Int J Syst Evol Microbiol 53, 1595-1599. 